\title{
CULTURAL INFLUENCE ON EVOLUTION OF ARCHITECTURE IN DELHI
}

\author{
Neha Thunga \\ Student, PES University, INDIA, nehathunga@gmail.com
}

\begin{abstract}
The evolution of 'culture' from a colony of bacteria to a complex structured society of human beings talks about socially inherited behavior and adaptation. Inheritance of cultural values and beliefs not only talks about sociology aspects but demonstrates Darwin's theory of evolution. Culture is a holistic character that is not just an addition of individuals but a unified outcome. It establishes a certain character that further defines the architecture, art forms, laws, beliefs, and customs. From the bronze age to the contemporary era, we witness the evolution of the architectural styles as an influence of its regional cultural system. Culture and architecture together give an identity to the region. History of architecture in India uncovers examples of monuments and settlements that have deep rooted concepts of cultural values expressed in their buildings. From the Portuguese rule to the British era, the evolution of lifestyle and cultural system was steered due to the ruling power. During the British era, the motive of 'colonizing' and 'civilizing' was very evident in every sphere of influence on politics, architecture, art and culture. The genesis of Indo Saracenic style became the statement of the colonial era, creating a limited purview of design philosophy across all states. This essay aspires to understand the evolution of Indian architecture due to the influence of culture in terms of its design character and elements during the British colonial period.
\end{abstract}

Keywords: Culture and architecture, history of architecture, colonial architecture, Indo-Saracenic

\section{INTRODUCTION}

From Qutub Minar to the Lotus Temple in the Delhi province, we have witnessed a bold transformation in the architectural styles as an influence of the governing religious and cultural praxis. Culture is a phenomenon that is the result of socially inherited behavior. People with similar interests and cultural traditions in a region bind together to form a society. It establishes a certain character that further defines the architecture, art forms, laws, beliefs, and customs. Culture and architecture together give an identity to the region. Culture is a way of living, while architecture transforms the cultural practices into a functional tangible structure. Throughout the history of architecture, we notice two major categories of structures. The significant buildings (forts, monuments, religious buildings) and the insignificant structures (settlements). The significant structures aimed at demonstrating the power of the ruling dynasty while the settlements were to serve as functional spaces for the local inhabitants as a result of their cultural norms. The National capital territory Delhi is one of the prime provinces to have witnessed a drastic architectural revolution from the Mughal era to the post-British colonial period. This essay aspires to understand the evolution of Indian architecture due to the influence of culture in terms of its design character and elements during the British colonial period. 


\section{CULTURE}

Culture can be defined as a set of beliefs, norms and practices of a region that gives it a distinct character. It is a system of distinctive accomplishments and traditions. It is expressed in various tangible and intangible forms. Society is shaped through its beliefs about race, ethnicity, religion, gender, sexual orientation, economic class, and more. Architecture becomes the tangible means of expression to reflect the "Way of life". It is the manifestation of culture, habits and values of a set of people in a region. Architecture is majorly influenced by the culture of a region and in process it may also in turn affect the existing cultural values. The architectural character and design principles are directly dictated by the culture of a region and hence it should acknowledge and respond to its values and needs.

\section{THE CULTURAL BACKGROUND OF INDIA}

Architecture, as an influence of culture, requires a faint knowledge of its history and evolution of the cities to appreciate the beauty of its elements. Since the historic period, we find evidence of cities and their buildings being designed in response to its people and the local customs. From the bronze age to the contemporary era, we witness the evolution of the architectural styles as an influence of its regional cultural system. The cultural impression is broadly a result of religion, identity, social life, politics and globalization.

Industrialization, migration and ease of connecting with different parts of the world has increased the use of man-made materials that were unheard of before. Before commuting to different cities became as easy as the present days, architecture was exclusive to its region, responding to its context and people. The concept of vernacular architecture governed the style of a place with locally available materials, craftsmanship and traditional art and crafts. Over the time, we observe architecture developing as a homogeneous design language in various countries, considering skyscrapers as an example

\section{THE COLONIAL ERA}

During the colonial era (1615-1947), the Indian subcontinent was under the jurisdiction of European colonial powers. From the Portuguese rule to the British era, the evolution of lifestyle and cultural system was steered due to the ruling power. Through the five centuries of being conquered by an outlander, the individuality started fading in the country. With the passage of time, the indigenous people and their culture are looked down upon as their beliefs and values are considered less civilized. It is important to understand and respect the history of any culture of a place as it survived through generations harmoniously and kept its people firmly rooted to their ethics.

During the British colonial period from 1615, we witnessed a drastic change in the architectural language and practices. Even though India was conquered by different empires, the British rule left a mark as they not only were interested in trading, but slowly overtook the administration and political power. The motive of 'colonizing' and 'civilizing' was very evident in every sphere of influence of the British rule, from politics to art and culture. The British imposed new architectural styles in all the prominent cities by building administration buildings, churches, libraries and museums. From the St Mary's church in Chennai to Rashtrapati Bhavan in Delhi, from Indo- Saracenic to neoclassical, the architecture became a result of the colonial style completely changing the vernacular architecture language. As traders, their expression through structures did not reflect on the local context. With modernization and industrialisation, prime cities all over the country started having a common architectural expression.

\subsection{The emergence of Indo-Saracenic Architecture}

The British architectural influence was seen on the churches at its earlier stages. The British period styles included gothic revival, baroque and neoclassical. During the initial ideation of the evolution of a new style, the emphasis was on creating a style that represents England. As British architecture established further, there were clashes between whether it had to follow neo-classical or gothic while the genesis of Indo Saracenic style became the statement of the colonial era in India in order to capture the indigenous character. It is the amalgamation of Indian and western architecture. It captures elements from Hindu temple architecture, Islamic architecture and the western architectural style. The architectural elements included domes, pointed arch, vaulted roofs, pinnacles, minarets, pierced open arcades and open pavilions.

Wood and stone were predominantly used during the earlier architecture and construction innovations. In the mid-18th century, the British administrators started to construct huge architectural wonders in the essential port cities of India. Early British architectural design composed of charts and outlined plans already erected successfully in England. During this period, the British desired to directly influence Indian design and details with western style. Later, extensive use of steel and concrete resulted in increased and faster construction. The secretariat north block, India gate, Mysore palace, Khalsa College at Amritsar, Victoria Memorial in 
Calcutta are a few examples that stand out as prominent structures that communicate through its style and grandeur.

New Delhi is a classic example of early 20th century colonial architecture. During the Delhi Durbar on 12 December 1911, while laying the foundation stone for the viceroy's residence, the capital of the British Raj was shifted from Calcutta to Delhi. Edwin Landseer Lutyens and Herbert Baker were appointed as the chief architects to design the new capital city of India. Sir Lutyens along with a group of architects designed the main central administrative district of the city that till date stands and houses principal buildings and residences of political and administrative importance.

\subsection{Architectural Elements}

The British did not understand the concept of vaastu shastra which was the defining factor of Indian architecture and hence rejected elements from it. The philosophy was majorly driven by religious factors of Hindu and Islamic architecture. The indo Saracenic style had its distinctive elements which evolved from ethnological and political divisions.

Indo Saracenic architecture emphasized on glorifying its rule and invincible character through its architecture and design elements. Further, the Indian architecture and building crafts were considered as separate components and the Indo Saracenic picked up only the aesthetic ornamental elements from the Indian architecture. In the late 18th century, the style further incorporated the local design details like motifs and decorations as part of its design character.

The most common elements of Indo Saracenic architecture were the domes with finials, pointed arches, turrets and marble inlay ornamentation. Each of the elements originated from the Hindu architecture but majorly Islamic architecture.

\subsection{Façade Treatment}

Indo-Saracenic architecture has a unique approach to a design with its distinctive facade elements. Since the British rule focused on establishing their power through constructing major administrative and public buildings, the scale of the structure in its context expressed its prominence. The elevations were detailed with various elements like higher plinth, triple height columns, minarets, openings and so on.

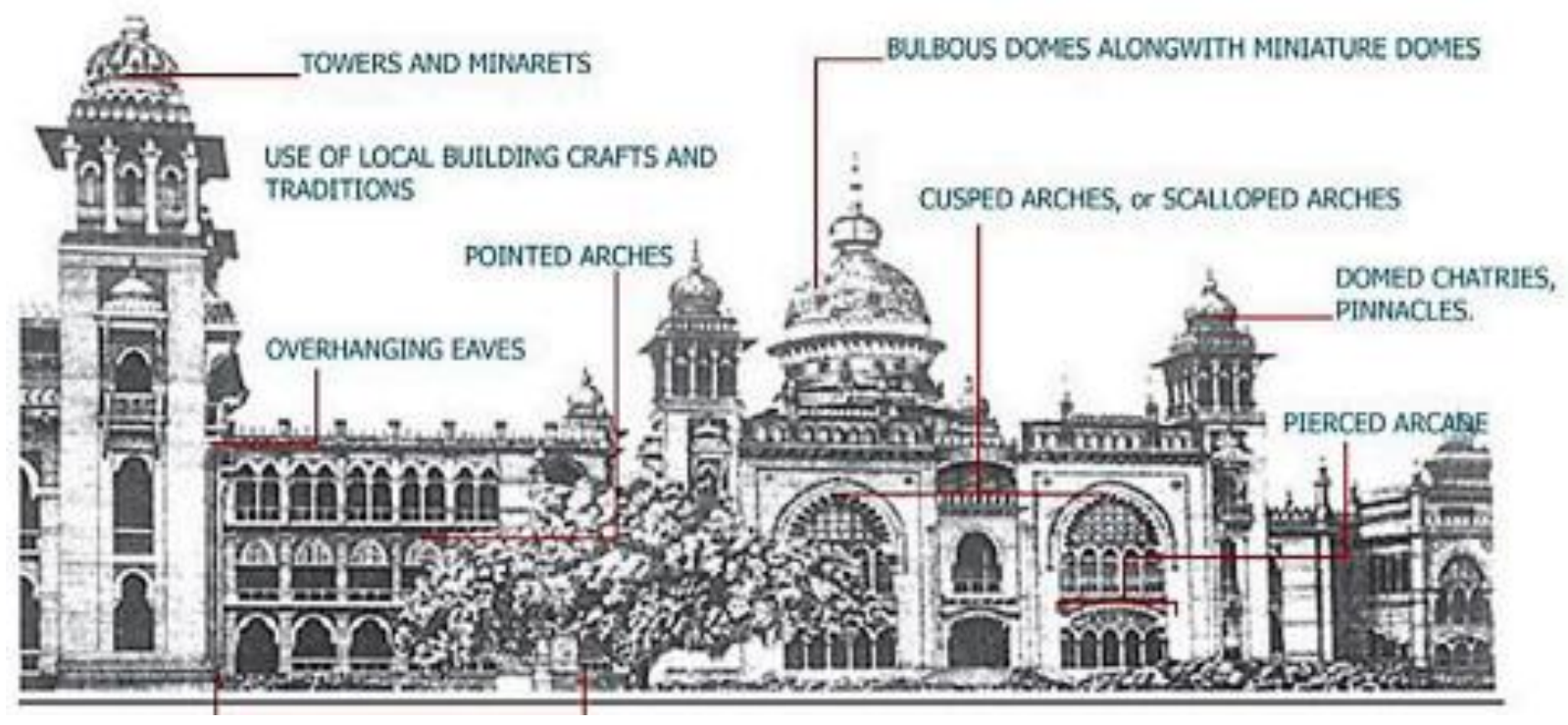

Fig. 1. Façade elements of Indo-Saracenic architecture

Indo Saracenic architecture articulates the vision on the horizontal plane with the striking scale of the central dome. The facade showcases a huge mihrab. The central dome usually is larger in scale compared to the other domes and sits on the octagonal drum base. The dome terminates with an Islamic finial or a kalash, influenced from vernacular architecture. The series of proportional arched openings on all levels give the facade a majestic appearance. The minarets are influenced by the Islamic architecture. It is in proportion with the central axis of the facade, creating a visual balance. The openings are recessed arches that act as shading techniques. The chhatris act as the ornamentation for the facade. The facade material predominantly used sandstone and white marble. Each floor is differentiated with a band of stone slightly projected out. The approach to all prominent Indo Saracenic structures was through a vast landscaped 
frontage usually influenced by the Mughal gardens with geometric plan. The facade style soon was made simpler and was also used in the bungalows of the British era.

\section{CULTURAL SIGNIFICANCE}

\subsection{Dome}

The geometric circle is considered as a symbol of perfection. The dome initially was a hemisphere placed on a square base. As the structure evolved, the dome was constructed on an octagonal base. The Bulbous dome also called as Qubba in Arabic, is a hemispherical structure evolved from an arch, usually forming a ceiling or roof. The dome acts as the crown to the structure similar to the shikaras in Hindu temple architecture. These domes are often used for large span structures. The Dome is considered as a symbolic representation of the vault of heaven. The internal surface of a dome is often decorated using intricate patterns or marble inlay calligraphy.

\subsection{Arch}

An arch portrays the idea of a new beginning and stepping into a new perspective of volume to experience the other side of the space. It is a symbol of renewal and initiation in many cultures. An arcade represents a path through the past into a new phase of the future. They manifest openness and strength. It elevates the vision to a higher plane. Arches act as a metaphor for 'move forward in life, and it only expands'. In terms of its structural stability, arches are used for longer spans and possess higher load capacity in comparison with beams or lintels due to their horizontal thrust.

The Islamic architecture extensively used arches both in exterior and interiors while Indian temple architecture used a trabeated system, reason probably being that the arch symbolized dynamism and the temples represented stillness and tranquility.

\subsection{Overhanging eaves}

It is a protruding structure which provides protection to the lower walls. The eaves are the threshold of the roof which overhang the face of the wall. The eaves form an overhang and are usually embellished as part of an architectural style. It acts as the chajja for the lower floors and reduces the heat gain of walls by casting shadow.

\subsection{Chhatri}

Chhatris are elevated, dome-shaped pavilions used as an element in Indian architecture. The word Chhatri means "canopy" or "umbrella". It consists of a raised platform girded by a set of ornate pillars which hold up a stone canopy. Chhatris are designed using a hierarchy of scales to mark the corners or entrances of the structure. These pavilions are used as aesthetic elements rather than as functional units.

\subsection{Minarets}

A minaret is a distinctive structure found adjacent to the main structures in Islamic architecture. It is a tall spire with an onion-shaped crown. Minarets are either free-standing or taller than the associated support structure. A base, shaft, and a gallery constitute the principal elements of a minaret. The design varied and evolved in response to time and context. Minarets provide a visual focal point. Stairs circle the shaft in a counter-clockwise fashion, providing necessary structural support.

The following analysis has been drawn based on the case study of 'Chhatrapati Shivaji Maharaj Vastu Sangrahalaya', Mumbai, India and 'Raza Library', Rampur, India. The intent of the case studies is to understand the architectural elements of Indo-Saracenic style in two cities of India with divergent vernacular style of architecture and analyze the predominant influence of colonial style through architecture in its context.

The CSMVS museum came into being after some of the city's most prominent citizens resolved to build a public museum, as a memorial to mark the visit of the Prince of Wales in 1905. It was designed by Ar. George written as part of a competition by the Bombay presidency. The Indo-Saracenic style combines Hindu and Saracenic architectural forms. At times incorporating some elements of Western architecture. The intent of building this museum was to establish a cultural institute in the city. The collection of the museum is categorized primarily into three sections: art, archaeology and natural history.

CSMVS has contributed significantly to the evolution of the surrounding neighborhood of Kala Godha as a center for artistic learning. It frequently hosts public programs including documentary film screenings, workshops and seminars for students and adults. The museum even hosts post-graduate diploma courses in 
museology and conservation, and heritage studies and conservation.

The Raza library started as an idea during the decline of the Mughal empire in order to preserve Islamic culture and its history. Libraries have always been an integral part of a society to educate its people. It had all the collections of Islamic culture and it was intended to pass on the traditions and culture to the future generations. It currently stands as a source to learn about Persian and Arabic history. The main purpose of the library is to extend all facilities for the general public as well as for researchers and to ensure preservation and protection of a vast collection of manuscripts, paintings and rare books. The library undertakes a project of publication of books on history, art and culture of medieval India. It also organizes workshops, seminars and holds special lectures for promotion of learning and creating awareness.

Table 1. Comparative Analysis

\begin{tabular}{|c|c|c|c|}
\hline Parameters & Best Practice & CSMVS Mumbai, India & $\begin{array}{l}\text { Raza Library, Rampur, } \\
\text { India }\end{array}$ \\
\hline Architecture Style & $\begin{array}{c}\text { Indo-Saracenic } \\
\text { Architecture }\end{array}$ & $\begin{array}{c}\text { Indo-Saracenic } \\
\text { Architecture influenced } \\
\text { by Maratha architecture }\end{array}$ & $\begin{array}{l}\text { Indo-Saracenic } \\
\text { Architecture }\end{array}$ \\
\hline Façade Treatment & $\begin{array}{l}\text { Distinct features of } \\
\text { Indo-Saracenic } \\
\text { Architecture }\end{array}$ & $\begin{array}{l}\text { i) Predominant use of } \\
\text { arches and domed } \\
\text { Chhatris } \\
\text { ii) Ratio of the length of } \\
\text { the south-west facade is } \\
\text { almost twice its height }\end{array}$ & $\begin{array}{l}\text { i) Symmetry } \\
\text { Dominant central dome } \\
\text { ii) Ratio of the length of } \\
\text { the south-west facade } \\
\text { is } 1.3 \text { times its height }\end{array}$ \\
\hline Roof Structure & $\begin{array}{l}\text { Vault roofs, Extensive } \\
\text { use of domes }\end{array}$ & $\begin{array}{l}\text { i) Central onion Dome } \\
\text { sits on an octagonal } \\
\text { base } \\
\text { ii) Flat roof with internal } \\
\text { intersecting arches and } \\
\text { vault structure }\end{array}$ & $\begin{array}{l}\text { i) Onion Dome sits on } \\
\text { an octagonal base } \\
\text { ii) Decorated ceiling } \\
\text { iii) Vaulted roof } \\
\text { corridors }\end{array}$ \\
\hline $\begin{array}{c}\text { Architectural design } \\
\text { Elements }\end{array}$ & $\begin{array}{l}\text { Distinct features of } \\
\text { Indo-Saracenic } \\
\text { Architecture }\end{array}$ & $\begin{array}{l}\text { i) onion dome with Finial } \\
\text { ii) Over hanging eaves } \\
\text { iii) Minarets } \\
\text { iv) Arched openings } \\
\text { v) Mughal garden } \\
\text { vi) Wada style wooden } \\
\text { railings }\end{array}$ & $\begin{array}{l}\text { i) Mehrab } \\
\text { ii) Minarets } \\
\text { iii) Marble columns } \\
\text { iv) Dome with Kalash } \\
\text { Finial } \\
\text { v) Lime plastered walls } \\
\text { vi) Balcony projections } \\
\text { with Arched openings } \\
\text { vii) Mughal garden }\end{array}$ \\
\hline Geometry in Elements & $\begin{array}{l}\text { Use Geometric shapes } \\
\text { in design elements }\end{array}$ & $\begin{array}{l}\text { i) Repetitive patterns on } \\
\text { traceries } \\
\text { ii) Pointed arches } \\
\text { Onion domes with iii) } \\
\text { Lotus petal drum } \\
\text { iv) Cusped arch }\end{array}$ & $\begin{array}{l}\text { i) Pointed arches } \\
\text { ii) Onion domes with } \\
\text { kalash (petal shaped) } \\
\text { finial }\end{array}$ \\
\hline Motifs \& Reliefs & Pietra dura & $\begin{array}{l}\text { i) Marble inlay on } \\
\text { columns }\end{array}$ & $\begin{array}{l}\text { i) Marble inlay on } \\
\text { columns }\end{array}$ \\
\hline
\end{tabular}




\begin{tabular}{|l|l|l|l|}
\hline & & $\begin{array}{c}\text { ii) Jali patterns } \\
\text { iii) Harem windows }\end{array}$ & $\begin{array}{c}\text { ii) Jali patterns } \\
\text { iii) Ceiling is decorated } \\
\text { with PoP }\end{array}$ \\
\hline
\end{tabular}

\section{INFERENCE}

British era has brought major changes over three centuries in all aspects, from politics, education, transportation and settlements. It propagated that the native architecture was uncompetitive of its uniqueness and hence the British imposed a new style through the genesis of Indo Saracenic architecture creating an orthodox design throughout the nation. Ignoring the rich historical values that each design element rendered the local culture, all public buildings started being an expression of the central colonial power. Indo Saracenic architecture has a bold expression of dynamism through its use of domes and arches in a repetitive fashion which deferred from the expression of Indian temple architecture. The basic philosophy of Vaastu, climatology and vernacular concepts were disregarded in the Indo Saracenic design. We see a major influence of Mughal architecture since they had conquered India before the British rule. The elements were merely to express the grandeur and power of the British. The colonial power created a temporary style that created a mark, but was forgotten and unused post-independence with the emergence of contemporary architecture ideology.

The evolution of culture from a colony of bacteria to a complex structured society of human beings talks about socially inherited behavior and adaptation. Inheritance of cultural values and beliefs not only talks about sociology aspects but demonstrates Darwin's theory of evolution. A society with its cultural values works towards a greater whole and not just as an individual part. It is a holistic character that is not just an addition of individuals but a unified outcome.

\section{CONCLUSION}

Architecture speaks in volume about the socio-cultural aspects of a region and recreates intangible principles into a space. It represents the behavior and user patterns of a society. Architecture is the reflection of one's thoughts and ideology and culture are an illustration of architecture. Art and architecture become key elements to study the evolution of civilization in any place. History of architecture in India uncovers examples of monuments and settlements that have deep rooted concepts of cultural values expressed in their buildings.

Elements in architecture have a huge impact in evoking emotions and inspire one to look beyond the mere tangible aspects of a space. Each design elemental concept inspired by the culture results in influencing lifestyle as well as wellbeing. Cultural values and beliefs that have evolved are well thought about and are unique to a society and have persisted over generations. The temple architecture is a classic example in transforming outward judgement to an inward perspective of thoughts. Places of worship have always had the core values depicted through architecture. The symbolism of elements, transition of spaces, scale, illumination, horizontal and vertical planes and every other aspect make a bold statement of what the culture portrayed.

To conclude, this paper comprises architectural aspects with respect to its response to culture. Design elements became the strongest representation of culture of any space. It has the power to bring in a sense of transcendence from the worldly matter to an inward approach on an individual level. With evolution in architecture styles from traditional to contemporary architecture, modularity, ease of construction and technological advancements have majorly influenced the design approach. The buildings fail to encapsulate ethnicity. For a culturally rich nation like India, it becomes important to inherit, implement and preserve our traditions and pass it on to further generations.

\section{REFERENCE LIST}

Antrolia, K., (2019b, November 20). B. Arch. Dissertation book.

Choudhary S., Dr Pipralia S., \& Dr Kumar N. (2018). Energy efficiency assessment of Indo-Saracenic 
buildings in India.

Dr Anita Sharma. (2018, March-May). An Analysis of Colonial Architecture in India. American International Journal of Research in Humanities, Arts and Social Sciences, 22(1), 91-95.

Home - Chhatrapati Shivaji Maharaj Vastu Sangrahalaya. (n.d.). Retrieved from https://www.csmvs.in/

J, S., \& Dhas, J. t. (2020, 03 08). A study on Indo-saracenic architectural heritage. International Journal of Pure and Applied Mathematics.

Kanwar, G. R. (2014). National repositories of India: a special case study of Rampur Raza Library, Rampur, Uttar Pradesh, India. International Journal of Recent Trends in Science and Technology, 12(1), 6.

L S Raheja School of. (n.d.). Reciting Libraries. College Publications.

S, S. (2019). Indo saracenic architecture. Pramana Research Journal, 9(7), 4.

Sariya, T. (2020, July 28). A look at British Colonial Architecture in India - Part I.

Shuja, S., \& Junejo, R. (2020). Appropriating Indo-Saracenic style: Bhai Ram Singh's contributions to the architectural identity of 19 th century Lahore. Journal of Traditional Building, Architecture and Urbanism, (1), 357-368.

Sisodiya, S. (2017, March 19). History Report on The Indo saracenic architecture.

Stephen F., Kenney, B.S. (1994). CULTURAL INFLUENCES ON ARCHITECTURE (master's thesis, Texas Tech University, Lubbock, Texas). 